\title{
THE LAST FIGHTING TOMMY: THE LIFE OF HARRY PATCH
}

\section{Harry Patch and Richard van Emden}

London: Bloomsbury

2008, pages 228

ISBN: 978-0-7475-9336-2

Possessing a good book, given the increasing costs of books, is becoming more and more challenging. And I am not only talking about the absurd high import taxes levied in South Africa. Hitting a button on Google will get you the relevant title more or less immediately and very virtual ("the age of the brutality of global plastic"1). For some exorbitant fee, you may offload the work. Using one of the digitally available points of global offset, you may order the relevant work at four or five times (or somewhat more than that) its original price via the internet. In countries that for reasons of exploitation or domination of others adhere to the copyright mentality, you may find the work in the original edition at about 10 to 15 times its original price. Being aware and with eyes wide open underpinned with a lot of human energy and the advice of valued friends, you will find a copy of the same work, frequently in a splendid condition, in a second-hand bookshop, the latter usually outside the parameters of city centres.

The good news apart from this is that if you travel to societies that value education and where the doors of culture and learning remain open, as colleagues who visited India, Pakistan, states in Latin America and Russia will testify, you will find such sought-after works at reasonable prices. To some extent, this also applies to the two Koreas and Vietnam. The downside is that the sought-after work may be translated into the indigenous language and you may not be a master of that particular language. In South Africa, getting hold of such works at affordable prices is virtually impossible: Under the apartheid government, works that were sponsored by government were those that advanced the ruling ideology of militarism and racism (read: works not banned, deemed 'undesirable' or restricted). Readable

Scientia Militaria, South African Journal of Military Studies, Vol 43, No. 1, 2015, pp. 156-159. doi : $10.5787 / 42-1-1114$ works obviously were also limited by the sanctions imposed on the apartheid state. Under the post-apartheid government(s), the possibilities of opening the doors of culture and learning were and are still severely 
undermined by high import taxes imposed to ensure a steady flow into state coffers. But, let me return to the main topic.

This book review is about the late Harry Patch, last survivor of the First World War. The subtitle of the The last fighting Tommy, namely The life of Harry Patch, the only surviving veteran of the trenches, provides a foretaste of what is to come.

One seldom finds a book where a personal life story, oral history, a partial auto-ethnography - in this case completed with the help of a trusted and dedicated participant and co-traveller such as Richard van Emden - come together. This life story/personal narrative came together 90 years after the event. Harry Patch's story certainly turned out a readable work.

Set within Britain before the First World War, carrying along the loaded webbing of history, exploring the harsh realities of the First World War, a short travel through the Second World War on the home front and long thereafter, this life story and reflected-upon experiences provide insights into past eras that can only be described as invaluable. This is not a dedicated history of battles, the strategies or strategists or single units or typifying the 'Other' as the ultimate evil. The broad background is the story of four years in which "statesmen and generals blundered while the massed armies of Europe writhed in a festival of mud and blood". 2 A madness inflicted on humanity by short-sighted political-financial elite and blustering militarists which, according to Taylor, led to "massacres, and mutinies ... the foulest war in history". 3 Taylor may have overstated the point that the First World War was the foulest war in history because since then, the Second World War, the Vietnam War and long-term conflicts and genocides overseen (and frequently instigated) by Western states in Africa, reduced the First World War to a definite foul war, but not the foulest ever. In his uncompromising statement that statesmen and generals play the foulest role, Taylor is correct, even if he missed out mentioning the role of capitalism as an exploitative system and its vested interests in large-scale violent conflict, in short, war.

In a series of interviews with Harry, Richard van Emden wrote up the life story of Harry with the First World War as crucial nexus. The reader is not only invited on this journey but briskly marches along and eventually finds him- or herself slogging along in the stinking mud, cordite, smoke and muck of a past war. Fortunately, Harry was prepared to share his story. He survived most others who went off to that war, survived the survivors and those political elite such as royalty, prime ministers and financial masters who sent him and many, many others to this war without any consideration for the death of their countrymen - or shall we say 'subjects' and cannon fodder? At the time of the publication of this book, Harry was 
107 years old and he was to live a number of years longer, with the personal reflection of "Why I am still here, I can't fathom." Only one year old when the Anglo-Boer War broke out in 1899, he became a reluctant conscript in the 'Great War'.

In providing a background and eventually a broad, yet intricate collage, the interviews completed over a number of years cover the life of Harry from early on, for example Victorian-born, Edwardian-raised, joining up for war, the trench experience and its existential decisions, pains, trials and tribulations. The Battle of Passchendaele (1917) deserves special attention. Harry Patch's experiences as a wounded soldier and his eventual demobilisation are dealt with. ${ }^{4}$ Harry's return to 'civvy street' and his experiences there as well as his later participation as part of Home Defence during World War Two are eloquently shared with the reader. I found the chapters entitled "Growing older" as well as "Life begins at 100" especially interesting. This text sharing the life experiences of a veteran soldier and his later reflection on these experiences are very personal and deeply human. Interwoven with Harry' story is also the story of his family and friends, which adds flavour to the work.

For those interested in qualitative research and (co-)storytelling, this work is a good example. The story is told without any pretensions, it is up close and personal, human reflection plays a role, including reflection on how to share these experiences. The two participants in the storytelling venture are intertwined while Harry remains the centrepiece. For those interested in qualitative research, ethnography, auto-ethnography and the telling of life stories, there is much to gain. Harry's story can be read together with other works on the First World War. After a hundred years, numerous works are available, among others in second-hand bookshops. Some of the books that I recall that I have read over the years that will provide a rich background and context to Harry's story are:

- $\quad$ The First World War: An illustrated history (1963, 1966);

- $\quad$ No man's land: The story of 1918 (1982);

- A brief history of The First World War: Eyewitness accounts of the war to end all wars, 1914-1918 (2003; 2014); and

- $\quad$ Forgotten voices of the Great War (1988, 2002, 2008). ${ }^{5}$

To conclude: Not to read the story of Harry will leave anyone interested in the First World War poorer.

Ian Liebenberg, Centre for Military Studies, Stellenbosch University 


\section{Endnotes}

${ }^{1}$ With apology and acknowledgment tendered to Petrus de Kock, friend, colleague, author, philosopher and academic. This book review also greatly benefitted from discussions with another friend and peer, Gert van der Westhuizen (Media 24), journalist and historian.

${ }^{2}$ Taylor, AJP. The First World War: An illustrated history. Middlesex: Penguin Books, 1967, quotation from cover page (back).

${ }^{3}$ Taylor, AJP. The First World War: An illustrated history. Middlesex: Penguin Books, 1967.

${ }^{4}$ The question of and challenges regarding demobilisation following modern wars and even in societies after protracted internal conflict or drawn-out low-level 'small wars' remain relevant. Compare demobilisation after South Africa's protracted struggle for liberation, which resembled a low-key civil war, in Liebenberg, I \& Roefs, M. Demobilisation and its aftermath: Economic reinsertion of South Africa's demobilised military personnel (Part II). Monograph Series No. 61. Lynwood: Institute for Security Studies, 2001.

5 Toland, J. No man's land: The story of 1918. London: Methuen Paperbacks, 1980; Lewis, JE (ed). The First World War: Eyewitness accounts of the war to end all wars. London: Robinson, 2014; Arthur, M (ed). Forgotten voices of the Great War. London: Ebury Press, editions appeared in 1988, 2002, 2008. 